\title{
The 'Law of Requisite Variety' may assist climate change negotiations: a review of the Kyoto and Durban meetings
}

\author{
$\underline{\text { Abstract }}$ \\ Ashby wrote about cybernetics during which discourse he described a Law that attempts to resolve \\ difficulties arising in complex situations - he suggested using variety to combat complexity. \\ In this paper we note that the delegates to the UN Framework Convention on Climate Change \\ (UNFCCC) meeting in Kyoto 1997 were offered a 'simplifying solution' to cope with the complexity \\ of discussing multiple pollutants allegedly contributing to 'climate change'. We assert that the \\ adoption of $\mathrm{CO}_{2} \mathrm{eq}$ has resulted in imprecise thinking regarding the "carbon footprint" - that is, \\ " $\mathrm{CO}_{2}$ ", to the exclusion of other pollutants.
}

We propose as Ashby might have done, that the $\mathrm{CO}_{2} \mathrm{eq}$ and other factors within the 'climate change' negotiations be disaggregated to allow careful and specific individual solutions to be agreed on each factor. We propose a new permanent and transparent 'action group' be in charge of agenda setting and to manage the messy annual meetings. This body would be responsible for achieving accords at these annual meetings rather than forcing this task on national hosts. We acknowledge the task is daunting and we recommend moving on from Ashby’s Law to Beer’s Viable Systems approach.

\section{Introduction}

Climate Change meetings are big business - at the 2009 Copenhagen meeting it was expected that there would be 1200 limousines, maybe 140 private jets; almost 100 world leaders (guarded by additional security personnel), another 15,000 delegates and officials and 5,000 journalists: about 40,000 visitors were accredited by the UN. The hotels were taken throughout the country. Some estimate the average cost to the taxpayer was about $\$ 14,000$ for each delegate, and overall each would generate about 40,500 tons of $\mathrm{CO}_{2}$. The Danish government, partnering with Bangladesh and the World Bank, agreed to spend 0.7 million euro on substituting 20 'new for old' brick kilns in Dhaka, which ought to offset some $50 \mathrm{~K}$ tons of $\mathrm{CO}_{2}$ pollution each year and significantly improve the local air quality (UNFCCC, 1999).

Over many years climate change studies have generated many arguments since no unambiguous causal relationship has been found. Forecasting, which is in effect 'hindsight looking backwards', stumbles over explaining succinctly the various biases inherent in data collection and analyses. For instance, what I think may be a valid data source, you may not, or I may innocently miss a data source, which you know about; or a lobbyist may ask me to accept or ignore specific data - there are 15,000 registered lobbyists in the US though only 1,500 in Europe. Having data, I may be guilty of a poor use of analytic techniques, especially in handling potential data outliers. It these are removed may result in better correlations, but must be left in the data set if there are no valid grounds for removal; and finally, the conclusions I might draw from analyses may be influenced by my biases. Other researchers with the same data may provide better or worse, or simply different results. Over time, through repeated analyses and pursuing the 'scientific process' to obtain replicable results, we may arrive at findings that frame an outcome which also carry statistically reliable bounds. Even then, 'theories in good standing' may be overturned at any time as new evidence is brought forward but that is the nature of science and adoption of evidence. 
The issues of 'climate change, global warming and anthropomorphic issues' have become political pawns. Giddens (2008) places argument firmly at the national political level, suggesting international cooperation depends on incremental developments at lower levels, but he affirms that wide scale coherence is usually missing. There is a continuing debate about global inequality and the North/South divide that is not yet addressed as the developed, undeveloped and 'lesser' nations debate in international meetings for their viewpoints to be heard. Roberts and Parks (2006) draw our attention to the lack of attention paid to such inequality and the plight of poor nations. But we cannot say that 'climate change' discussions have been hijacked only by current politicians. Marx argued against capitalists raping the planet: see, for example, his ‘Economic \& Philosophical Manuscripts' of 1844 published by Progress Publishers, Berlin. Many others have since followed his line of argument.

We must take into account the various lobbyists pressing for several, possibly divergent, goals. At the UNFCCC meeting in Durban (December 2011) there were the 'low lying island kingdoms' arguing that climate change, meaning global warming, was raising the sea level and flooding their homelands; and the Alliance of Small Island States continues to present its case (Aosis, 2012). As an additional complexity there are other aspects of 'the human condition' that ought to be addressed under the auspices of 'climate change' that are presented in the Millennium Development Goals (UNDP, 2000).

In this paper we will assume that a distinct change in climate is occurring, though the extent to which it may be attributed to human generated activity is not considered. Herein we only consider a small but crucial aspect - that of cognitive complexity; and how it may be managed in the UNFCCC meetings.

In the following sections we will consider Ashby's Law (Ashby, 1956; 1958) which we will link to the climate change arguments, mainly about the effects of pollutants inducing climate change. Then we move on to a brief description of Beer's Viable Systems Management (VSM) (Beer, 1972; 1979; 1981). We will indicate how, in our opinion, the delegates at Kyoto in 1997 were seduced into the acceptance of the $\mathrm{CO}_{2}$ eq measures to be used as a shorthand abbreviation encompassing all pollutants in subsequent discussions. We explain why we think that the $\mathrm{CO}_{2} \mathrm{eq}$ loading ought to be disaggregated to provide specific individual solutions to be agreed across all factors. Finally, because this has now become an extremely difficult organisational responsibility, we recommend it is necessary to create a new permanent team to manage the processes of debate at the annual meetings and not to rely on the COP - the Committee of the Parties - which at present is the highest decision making body of the UN Framework Convention on Climate Change. These new teams would be constituted according to Beer's VSM framework.

\section{Law of Requisite Variety}

Ashby wrote:

It has been found repeatedly in science that the discovery that two branches are related leads to each branch helping in the development of the other. The result is often a markedly accelerated growth of both. The infinitesimal calculus and astronomy, the virus and the protein molecule, the chromosomes and heredity are examples that come to mind. Neither, of course, can give proofs about the laws of the other, but each can give suggestions that may be of the greatest assistance and fruitfulness. Here I need only mention the fact that cybernetics is likely to reveal a great number of interesting and suggestive parallelisms between machine and brain and society (Ashby, 1972: 4). 


\section{Ashby's contribution}

Consider the temperature in a room which is thermostatically controlled by a sensor. As the room temperature falls (perhaps due to the outside temperature falling) the sensor clicks 'on' and heating is applied up to a pre-set goal (set by someone as the desired room temperature). After the room reaches the level, the sensor switches off the heating source. Thus the heating will cycle on/off and the room remains, within bounds, at a constant temperature - based on feedback of information from the sensor to the controller of the heating system. Ashby said, in active (feedforward and/or feedback) regulation each disturbance $\mathrm{D}$ will have to be compensated by a uniquely appropriate counteraction from the regulator $\mathrm{R}$. If $\mathrm{R}$ would react in the same way to two different disturbances, then the result would be two different values for the critical variables and therefore imperfect regulation. This means that if we want to limit the effect of $\mathrm{D}$, the regulator must be able to provide at least as many counteractions as there are disturbances in $\mathrm{D}$. Therefore, the variety of $\mathrm{R}$ must be at least as broad as the variety of $\mathrm{D}$. We ought also to be aware of the need for sufficient information flow capacity.

Ashby has called this principle the law of requisite variety: in active regulation only variety can destroy variety. It leads to the somewhat counterintuitive observation that the regulator must have a sufficiently large variety of actions in order to ensure a sufficiently small variety of outcomes in the essential variable $\mathrm{E}$. Often systems may have a buffer $\mathrm{K}$, such as a reservoir that ameliorates the effects (of rainfall, at any instant) against the demands (for more or less constant river water supply). The formula is

$$
V(E)=V(D)-V(R)-K
$$

This principle has significant implications for many practical situations. Since the variety of perturbations with which a system can potentially be confronted is unlimited, we should always try to maximize its variety (or diversity) so as to be optimally prepared for any foreseeable or unforeseeable contingency.

\section{Other contributors}

There are several branches of science that may contribute to this discussion, but we will only highlight one - cybernetics studies - and only one researcher, Stafford Beer. Beer suggested that Ashby contributed fundamentally to the development of cybernetics as Ashby focused on the control of complex systems - a firm, or a government for instance. Beer has likened the activities of a firm to the organisation of the human brain (Beer, 1972; 1981). Thus, according to Beer, management cybernetics is the application of cybernetic laws to all types of organizations and institutions created by human beings, and to the interactions within them and between them. To this end Beer developed the Viable Systems Model (VSM) to describe the management interactions at all levels of a complex system (Beer, 1979; Espejo \& Harnden, 1989). We should note that 'management interactions' encompass variety, information flows and thus complexity: we might redefine the world's problem as one of managing complexity.

Beer's model rests on the concept of the recursion of a set of systems. System One describes the fundamental operations of an enterprise and System Two relates to co-ordination through a regulatory centre for each element of System One. System Three applies control to System One and supervises System Two. System Four refers to the feed forward and feedback of intelligence to and from System Three. System Five's primary function is policy formulation guiding intelligence gathering (System Four) and therefore the management of Systems Three, Two and One. Effectively each level recursively contains a mimic of the complete VSM. There may be multiple System Ones working 
within a domain and thus managed by higher levels. Unfortunately, managers often find they are confused about their operations at levels 3,4 or $5 \ldots$ often moving too freely between the functions: they do not know 'which hat to wear' (Hilder, 1995).

\section{Pertinence to climate change}

We may note that complexity increases when the variety (diversity) and dependency (connectivity) of parts or aspects increase, usually in several dimensions. These include at least the usual three spatial dimensions and the dimension of time and its dynamics. As we will see below, climate change is not limited to only one [complex] $\mathrm{CO}_{2}$ cycle but has many potential contributions whose science remains uncertain. In addition, we must address the social and psychometric drivers of the hundreds of world leaders who meet to 'manage' climate change in the annual meetings of the UNFCCC. They perhaps ought to be working as System Three, but I feel they are actually at System One. They tend to concentrate their discourse upon how to devise a System Three controller while under the influence of a misconceived System Five (the local host contriving to determine an agreed solution for global acceptance by the COP). As Hilder notes, bundling work together at levels 3,4 and 5 is confusing to all actors and observers: we suggest this is occurring at the UNFCCC meetings with System Five (the UN) not able to define policy across the board.

Within this paper I take the view that the systems we will discuss are complex (having much variety and interdependence) and it is complexity management that will be the key to future success of UNFCCC meetings. Some detail of the complexity may be found at UNFCCC (2012: Key Data) which offers descriptions of 'Negotiations, Processes and Key Documents'. Of course, that Web site will be maintained from time to time offering further information on meetings and agreements.

\section{Climate: science, pollution, and governance}

This aspect comprises an extensive literature both scientific and popular: there is even a strong literature condemning the idea of 'climate change' denying that there is any man-made (anthropomorphic) effect and that the evidence accrued 'is simply ... a natural evolution'. Herein we will assume that many sources provide clear evidence for change, but also that there is no strong case for a tightly defined causal relationship. The following sections will give a brief summary of 'climate change'.

\section{The science - very briefly}

The modern history of climate change is well-documented by the science-historian Spencer Weart (2008) and in his web site supported by the American Institute of Physics:

The scientists who laboured to understand the Earth's climate discovered that many factors influence it. Everything from volcanoes to factories shape our winds and rains. The scientific research itself was shaped by many influences, from popular misconceptions to government funding, all happening at once. A traditional history would try to squeeze the story into a linear text, one event following another like beads on a string. Inevitably some parts are left out. Yet for this sort of subject we need total history, including all the players - mathematicians and biologists, lab technicians and government bureaucrats, industrialists and politicians, newspaper reporters and the ordinary citizen. This Web site [... of the AIP] is an experiment in a new way to tell a historical story. Think of the site as an object like a sculpture or a building. You walk around, looking from this angle and that. In your head you are putting together a rounded 
representation, even if you don't take the time to inspect every cranny. That is the way we usually learn about anything complex.

Extracted from http://www.aip.org/history/climate/summary.htm Accessed $10^{\text {th }}$

September 2012.

Stimulated by the need to monitor tiny volumes of radioactive gases resulting from atomic testing, the US government supported several studies that had a direct impact on climate change models, notably the ability to measure the $\mathrm{CO}_{2}$ carefully in the atmosphere (Revelle, 1955; Keeling, 1976). In fact, the 'Keeling curve' has become a modern icon, displaying annual incremental changes of atmospheric $\mathrm{CO}_{2}$ concentration beginning in 1956. Other researchers looked in old timber (Stuiver \& Suess, 1966), old ice (Hammer et al (1986), or old rocks (Hansen et al (2007): all relate $\mathrm{CO}_{2}$ concentrations to distinct events such as volcanic eruptions or to significant ecological events.

It is almost inevitable that 'climate change' and 'global warming' have become synonymous. Yet the two are distinct due to the non-causal relationship between climate change and global warming. It is true that change may be seen, as with the Keeling Curve (attributable to mans' greater propensity to pollute); but global warming may occur through various mechanisms: the foremost is the potential for $\mathrm{CO}_{2}$ to raise the temperature through complex atmospheric changes. This paper will not take a particular stand on the interchangeable use of these two phrases - it is concerned with complexity and the organisational chaos in large meetings.

\section{Fuel consumption, pollution and trade}

Until the Industrial Revolution, beginning in the mid-1700, in England, we used little fossil fuel. Once the newly invented steam engine had become smaller, lighter and more powerful it could be used to power trains, road vehicles and ships. Coal became the premier fuel and all trade systems benefited from faster logistics exchanges, albeit producing more pollution. Coal also became more widely used to make coke for the iron industry, for fixed steam engines to power factory machines, and for home heating. Coal was broken down into its chemical components to synthesize drugs, as well to make 'town gas' for lighting streets, offices and homes.

Pollution increased rapidly in all industrialized nations leading to heavy, sour fogs in large towns in winter thus raising the death rate of people with respiratory weakness. The burning of coal in household open-fires has been banned globally in most developed regions so those "pea soup" fogs caused by coal fumes do not form, but as the global economy has rapidly grown, so has its need for a greater energy supply. Coal is still used widely for electricity generation, and much coal is used as a source of chemicals. Figure 1 indicates that world energy demand has increased by about one-third since 1986 and that demand is met more by coal than oil and gas. The nuclear power industry is significant, though currently in turmoil due to popular anxiety after the Fukushima disaster: renewable energy sources like wind and hydro- power are increasingly 'harvested'. 


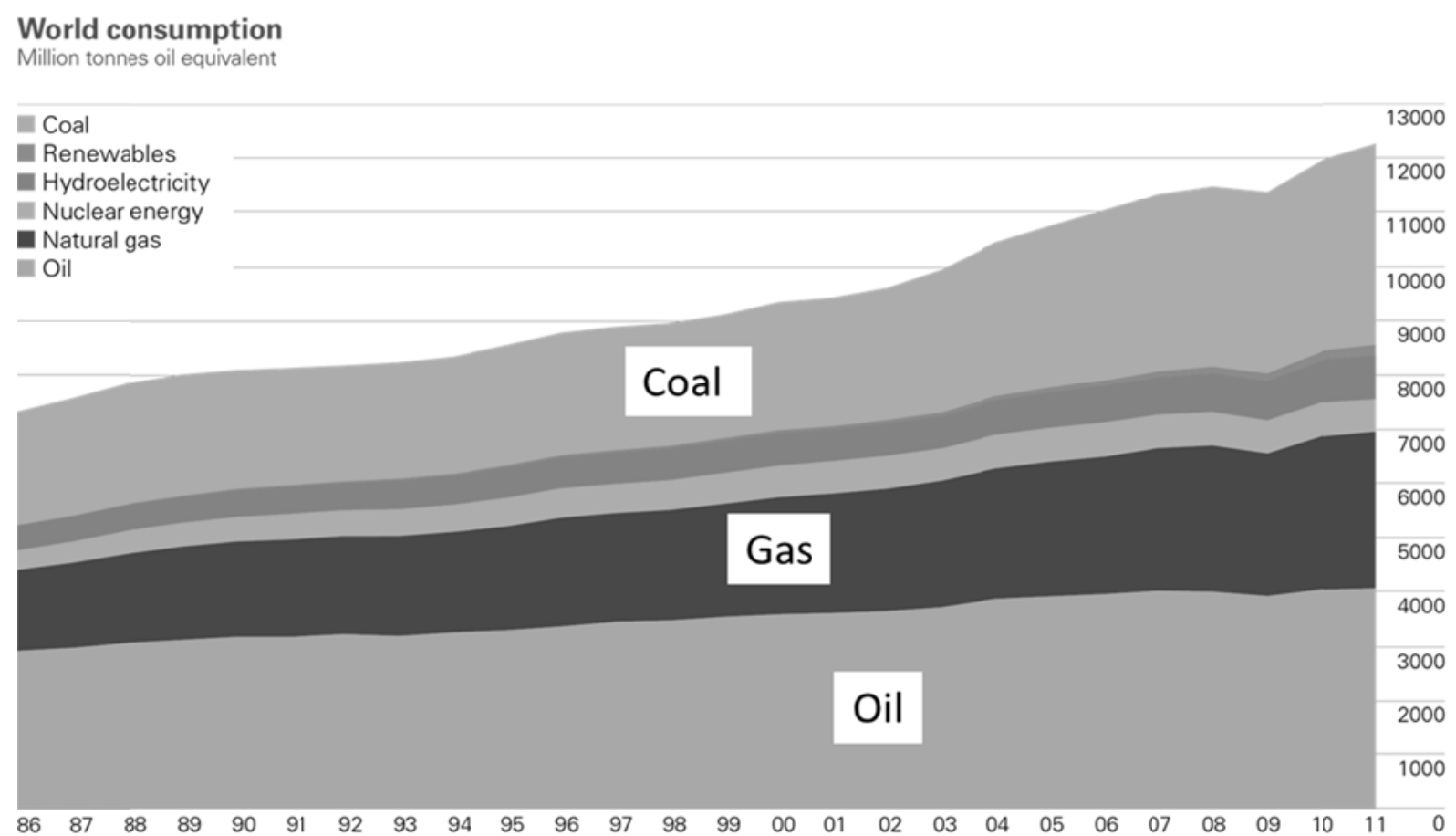

World primary energy consumption grew by $2.5 \%$ in 2011 , less than half the growth rate experienced in 2010 but close to the historical average. Growth decelerated for all regions and for all fuels. Oil remains the world's leading fuel, accounting for $33.1 \%$ of global energy consumption, but this figure is the lowest share on record. Coal's market share of $30.3 \%$ was the highest since 1969.

Source: BP Statistical Review of World Energy 2011

\section{Figure 1: World Energy consumption}

The flue gas at power stations is cleaned imperfectly of various chemicals, but they still emit $\mathrm{CO}_{2}$, other pollutants and small solid particulates. And electricity carries considerable upstream pollution: ie the $\mathrm{CO}_{2}$ 'cost' of the mining of coal, its delivery to a power station, and its burning; plus the carbon cost of building mines, railways, power stations, electrical transmission systems and their decommissioning. This 'carbon cost' can be reduced to half by using natural gas as a primary fuel, or reduced almost to zero with the nuclear fuel option. The upstream lifecycle loading for coal generation is $\sim 1000 \mathrm{gmCO}_{2} \mathrm{eq} / \mathrm{kWh}$ while the nuclear option has a $5 \mathrm{gmCO}_{2} \mathrm{eq} / \mathrm{kWh}$ loading [note $\mathrm{CO}_{2} \mathrm{eq}$ is the result of computing the effect of other pollutants into a total $\mathrm{CO}_{2}$ equivalent] (POST, 2006; EIA, 2009). When discussing national pollution levels, in addition to the direct fuel use by industry, commerce and transport, one must always consider the national fuel mix that generates their electricity. As a result each country has its own pollutant profile.

By 2001, the Kyoto delegates saw a worrying rapidly increasing trend of the global consumption of fossil fuels. This is a natural effect as they are tied to global production and trade: oil especially, as this is the primary fuel of transportation systems.

Oil can be used for electricity generation. Over $66 \%$ of oil extracted is used by transport - in road or rail engines, for aircraft, and in ships (EIA, 2009), with large, modern container ships using 300 tons per day of cheap but dirty 'bunker fuel'. Shipping produces large volumes of pollutants per ton delivered, yet air freight is spectacularly more polluting, burning about 150,000 gallons of fuel on a 10,000 kilometre flight (eg. from China to Europe).

We illustrate the range of transport mode pollution in Table 1 with 2009 data (using $\mathrm{CO}_{2} \mathrm{~kg} / \mathrm{ton}$ delivered as the measure of pollution while delivering a 'load' - a TEU [twenty foot container] usually carrying about 14 tons of cargo). Only shipping and air are suitable for pancontinental traffic, with 
large ships carrying upwards of 10,000 TEU (maybe 150,000 tonnes of cargo) while the largest air freighters carry only 6 TEU (about 100 tonnes), but do so quickly.

Table 1: Transport pollution \& unit load

\begin{tabular}{|l|c|r|}
\hline$\ldots$ their engines* are said to be ‘... the most efficient’ & CO2 kg/tonne & TEU \\
\hline Diesel/electric rail (Vossloh ‘Euro 4000’ engine) & 50 & 156 \\
\hline A heavy road truck (Mercedes-Benz Actros) & 200 & 2 \\
\hline Large container ship (Wärtsilä-Sulzer engine) & 400 & 10,000 \\
\hline Boeing 777F (purely air freight, no passengers) & 5,500 & 6 \\
\hline
\end{tabular}

Sources: * manufacturer's literature

\section{Governance - by expert panels and negotiators}

\section{The Montréal Protocol (1987)}

One of the most positive global reactions to climate change resulted in an attempt to 'close the ozone hole' (UNEP, 2010). Ozone is toxic, and it is a gas with 'global warming potential': it is also beneficial since it absorbs the harmful ultra-violet radiation. In brief, scientists found two undesirable atmospheric processes (i) a general dilution of the ozone concentration in the stratosphere, by about $4 \%$ per year, and (ii) a seasonal decrease in the 'thickness' of the ozone layer over the polar regions, most noticeable in the Spring. It was the second aspect that created global understanding when Farman et al (1985) published a report defining the field, and the Press published satellite images coining the phrase "ozone hole". The main culprit was the chlorofluorocarbon (CFC) family of chemicals although they had passed the applicable Environmental and Hazard tests (but not initially tested at high atmospheric levels where eventually they were found to decompose and combine with ozone). The CFCs were cheap; they were exceptionally good as refrigerants, propellants in aerosols, and as solvents: one branch of the family was a highly effective fire retardant against oil or electrical fires (Benedick, 2004: 3).

Media exposure led to a global outcry for governments to "do something ...” resulting by 1994 in a 66\% collapse in purchasing of CFC-based aerosols in the US (Benedick, 2004: 4). The reasons for this were in part explained by Dr. Mostafa Tolba, former head of the UN Environment Programme, who was quoted in the $30^{\text {th }}$ June 1990 edition of The New Scientist, “... the chemical industry supported the Montréal Protocol in 1987 because it set up a global plan for phasing out CFCs, [which were ...] no longer protected by patents. This provided companies with an equal opportunity to market new and more profitable compounds”.

Whether it was due to the public protests and/or the commercial strategies of chemical firms the result has been a sustained reduction in the 'hole', and thus a potential benefit to mankind. Most nations by 1996 had complied in the removal of freons (chloroflurocarbons: refrigerants and solvents) and halons (bromoflouocarbons: fire suppressants) by substituting other chemicals from their products.

\section{Climate forums: the players (IMO, WMO, IPCC \& UNFCCC)}

Many national meteorological departments are branches of the military - in 1854 the UK meteorological office was set up to serve its Navy, and even today remains a division of the Ministry of Defence. In the following year the first International Meteorological Conference was held in Brussels, which led to the inauguration of the International Meteorological Organisation (IMO) in 
1873. By 1950, the IMO morphed into the World Meteorological Organisation (WMO), which in 1988 with the United Nations Environment Programme set up the Intergovernmental Panel on Climate Change (IPCC) to overview all research on climate change, and mandates regular expert reports: the current (the Fourth Report) was issued in 2007 (IPCC, 2007) and the next is due in 2013/4. This Panel holds frequent meetings and colloquia so it garners and disseminates much evidence-based science.

In parallel, 195 countries agreed a UN Framework to assess the climate change challenge. By March 1992 the United Nations Framework Convention on Climate Change (UNFCCC) began to consider what could be done to limit the average global temperature increase and the ensuing climate change: they wrote The Convention document (UNFCCC, 2012: Key documents). Under the auspices of the UNFCCC many meetings have taken place, the most notable being - Kyoto (1997) with its 'Protocol' having binding targets and coming into force by 2005, Bali (2007) its 'Road Map' illustrating the way forward, and Cancún (2010) with its 'Agreements'. At the meeting in Durban (December 2011) it was hoped an agreement over all 195 nations would ratify an extension of the Kyoto Protocol and to impose this by 2020. Note that these UN meetings, for example, 'Cancún (2010)' are not citations but dates: details of all meetings may be found at UNFCCC (2012: Key data).

There is an additional parallelism: in 1972, the United Nations Conference on Environment and Development (UNCED) convened the first World Summit in Stockholm, Sweden. Here, government leaders declared their intention of reconvening every ten years in order to reassess the condition of the planet. The most notable of these was known as the Rio Summit, or Earth Summit, held in Rio de Janeiro in June 1992. Later UNCED convened the Rio+10 (Johannesburg in 2002), and the Rio+20 (again in Rio) in June 2012.

All these groups influence discussions on 'climate change' and no doubt cause meetings to become extremely complex as facts, scientific forecasts and political pressures all interact. After the climate summits in Copenhagen (2009) and Cancún (2010) the only international consensus that has emerged is that global temperature rise should ideally be limited to two degrees Celsius and that emission policies should be determined at the regional (e.g. European), national and city-level while the role of the UN should be primarily to monitor and co-ordinate these bottom-up policies. As a result there are no action points other than the $2^{\circ} \mathrm{C}$ limit: there are no mandatory methodologies for $\mathrm{CO}_{2}$ reduction, nor any 'owners of processes'.

\section{The Kyoto delegates dilemma}

The scientific study of climate change was supported by the IMO initially, by the WMO after 1950 and from 1988 by the IPCC. Reporting was continuous across many aspects, and was always somewhat controversial as the underlying systemic mechanisms were (and still are) not well understood. By the time of the UNFCCC meeting in Kyoto (1997) the delegates knew they had to consider more than one chemical group. Furthermore, the IPCC had advised that each gas had a different potential towards global warming that was not necessarily constant over its [long] lifetime, and that regulators often consider the "100-year Global Warming Potential (GWP)".

Table 2: Multiplier effects of pollutants contributing to $\mathrm{CO}_{2}$ eq and to GWP

\begin{tabular}{|c|c|c|c|c|c|c|}
\hline & Carbon & Sulphur & Nitrogen & Methane & CFCs & Soot \\
\hline $\begin{array}{c}\mathrm{CO}_{2} \mathrm{eq} \\
\text { weighting }\end{array}$ & 1 & 24 & 310 & 21 & 2,000 & 0 \\
\hline
\end{tabular}




\begin{tabular}{|c|c|c|c|c|c|c|}
\hline $\begin{array}{c}\text { GWP 100-yr } \\
\text { weighting }\end{array}$ & 1 & $\begin{array}{c}23,000 \\
\text { as }^{\mathrm{SF}_{6}}\end{array}$ & $\begin{array}{c}300 \\
\text { as } \mathrm{NO}_{2}\end{array}$ & $\begin{array}{c}25 \\
\text { as } \mathrm{NH}_{4}\end{array}$ & $\begin{array}{c}15,000 \\
\text { as HFC23 }\end{array}$ & 0 \\
\hline
\end{tabular}

Source: IPCC, 2007

The main greenhouse gasses are water vapour, carbon dioxide, methane, nitrous oxide, ozone and the chlorofluorocarbons - these absorb sunlight, reflect sunlight and also re-radiate. It is argued that following the Industrial Revolution mankind has raised the 'natural' levels of greenhouse gases and accelerated 'abnormal' global warming. The IPCC suggests these gases, if left to accumulate freely, would result in a catastrophic event: but because of the variety of drivers it is not yet possible to predict accurately how, what, and when.

Table 2 indicates how the greenhouse gases are weighted in the $\mathrm{CO}_{2} \mathrm{eq}$ loading and how they contribute to the 'potential' to global warming. The first row of data allowed the Kyoto delegates to discuss the main sources of pollutants, be they road vehicles, power stations or other sources of pollution. The key aspect discussed was the $\mathrm{CO}_{2}$ produced by burning fossil fuels; the secondary factor was the long-term contribution of the other polluting chemicals. One may see $\mathrm{CO}_{2}$ is not perhaps the most significant nor long-lived pollutant. Of course all pollutants demand control, but $\mathrm{CO}_{2}$ was the most easily addressed as it derives from all the fuels we use.

\section{$\underline{\text { Discussion }}$}

The Montréal process

Ashby's Law suggests that a regulator may achieve stability in a complex process provided the regulator is capable of handling sufficient complexity - to at least match the complexity of the process. Further, the communications channels must have sufficient capacity to inform the regulator of all the variety of the process. From this brief description we may infer that the regulator for ozone control only needs to be simple: pass usage data to the appropriate authority about the cessation rates, and to consider how long all users will need to achieve the goal of zero use of CFCs.

It would seem that the main production firms and users of CFCs were scanning the scientific literature while Molina \& Rowland (1974) broached the subject. The first industry reactions were angry and sceptical, but further science confirmed the findings (Farman et al, 1985), which informed the commercial strategies of chemical firms. As the US had officially banned CFCs as a propellant in aerosols by early 1978 user firms became involved in the meetings that led to the signing of the March 1985 Vienna Convention to Protect the Ozone layer. The United Nations Environmental Protection (UNEP) programme gathered all members of the UN to adopt the Montréal Protocol in 1987, following which the actions became law within 90 days. It was not all 'plain sailing' since there were still protesters holding forth that "there was no problem" - but the people were well informed, especially in the US (Morrisette, 1989). Responding to public reaction, US Congress authorized the Administrator of the Environmental Protection Agency (EPA) in the 1977 Clean Air Act “... to regulate... any substance which in his judgment may reasonably be anticipated to affect the stratosphere, especially ozone in the stratosphere, if such action may reasonably be anticipated to endanger public health or welfare" (Benedick, 2004: 4).

Thus an Ashby regulator was in place following the Montréal meeting, and reporting progress to the UN commenced. By 1996, all but a small amount of CFC was removed from general manufacturing (some laboratory or clinical use is allowed, but is being phased out). As a result the atmospheric ozone levels have stabilized, and the 'hole' is decreasing in size: though in 2006, the 'hole' was noted 
as being almost the largest ever seen. This was said to have been caused by the residual presence of ozone destroying substances in the atmosphere combined with a particularly cold stratospheric winter.

The Montréal process took place over several years but was aided by (a) being tightly focused on 'ozone issues' using a composite weighting function that combined effects of all CFCs into a single number, it actually concerned only one chemical family; (b) having firms cease CFC use much earlier than the convention date, given international pressure supported by the US having already banned CFC use in aerosols; (c) the CFC sector in each country did not include the entire spectrum of their national economy and (d) having a well-informed public demanding the easy to visualize 'ozone hole' be filled in as soon as possible to protect their personal health.

\section{The Kyoto process}

In Kyoto (in 1998) the regular delegates were present (190+ UN members), but there was no consensus about issues, causes, and solutions relating to global warming. Instead, the Press reported bickering, with many vague bilateral breakout meetings way into the night - bringing new but divisive suggestions to the main forum the next day.

Indeed, disagreement was almost guaranteed since the United States formally lacked commitment to the discussion process by Presidential edict. Remembering the lack of progress at the UNCED (Rio, 1992) meeting about pollution mitigation, the non-binding Byrd-Hagel Resolution was agreed by the U.S. Congress in early 1997. This resolution had two main points:

- The U.S. will not accept an agreement to reduce greenhouse gas emissions that will be detrimental to the economy of the U.S.

- The U.S. will not accept an agreement to reduce greenhouse gas emissions that do not require "meaningful participation" on the part of developing nations.

Of course there were 'detractors' who were demanding other restrictions... on nuclear generation of electricity and severe restrictions on the use of fossil fuels. Their fight against nuclear power was impressive as it has resulted in the near collapse of the nuclear energy industry since few new power stations have been built, though many are planned; and there is a concomitant collapse in all its support industries ranging from the education of new nuclear specialists to the forging of heavy pressure-vessel containment systems (Schneider \& Froggatt, 2008).

Well before Kyoto researchers had discovered many new facts, especially relating to the lifecycles of the GWP chemicals: see for example (UNFCCC, 2012: Process/Methods and Science). Also, the UNEP with the US Energy Information Administration (EIA) had calculated a different weighting function $\left(\mathrm{CO}_{2}\right.$ eq or the "carbon footprint") to allow negotiators to simplify the discussion of the complexity of the new set of pollutants (as per Table 2).

Why didn't Kyoto run as smoothly as Montréal? This author contends the complexity was too broad to be absorbed by the delegates and thus be forged into an agreement.

Recall, at Montréal, the weighting function concerned only a narrow chemical family (the CFCs) relating to a strong causal relationship towards ozone depletion. The information flows about potential and actual compliance were easy to develop; public opinion was well informed and highly supportive of a solution being found; commercial firms had already committed to the restrictions on CFC use with acquiescence towards substitution, and governments knew the economics of CFC use were restricted to a few sectors of their national interest. 
At Kyoto, although the weighting function concerned only a few chemicals, their emission spanned all economic activities across the globe - all industries and households would be affected directly and indirectly. Public opinion was confused - were the chemicals to blame, was it only a natural effect that raised or lowered temperatures, were glaciers melting or not, what did it all mean? Further, the people became too focused on carbon, or $\mathrm{CO}_{2}$ as the primary driver of global warming - they talked openly of 'the carbon footprint' and seemed to forget that the footprint was from a weighting function, not only of $\mathrm{CO}_{2}$ itself, but all other atmospheric warming gasses. Industrial firms were violently opposed to regulation of any type. Most firms were $\mathrm{CO}_{2}$ producers and were worried, but others who emitted different chemicals were relieved to keep quiet when the carbon footprint was discussed. Further, government negotiators mindful of their weak domestic position (often personally beholden to their electorates or lobbyists) were reluctant to compromise any position.

Nevertheless partial solutions were agreed at Kyoto: 141 nations ratified a convention accounting for $60+\%$ of all emissions, and they moved to reduce their national pollution to historical levels. Daily we all may observe some of their actions. There is more ethylene in transportation fuels reducing their overall carbon loads (but with the attendant issue of ethylene's own $\mathrm{CO}_{2}$ loading under some of its production regimes); we cannot now purchase incandescent light bulbs (they produced only 5\% light while dissipating $95 \%$ of the incoming energy as heat) so we must use more modern efficient units; coal is being substituted by oil or natural gas in some electricity generation, and more nuclear generation or electrical generation from renewables is in operation or planned.

The basic breakdown at Kyoto came from a regulatory process that could not cope with the complexities of the global economy and the environment. There were too many [national] government fears concerning the entire spectrum of their economies, too many lobbyists from leading businesses, too many contentious NGOs, too many disagreements about the science. In fact, the whole of the Kyoto process was served badly by its inability to give enough information to its delegates - the Law of Requisite Variety says that R's capacity as a regulator cannot exceed R's capacity as a channel of communication.

If we reconsider Kyoto via the lens of Beer: to deal with the massive variety multiple System Ones demand co-ordination by recognised and accepted System Twos with further control and guidance administered by higher levels. The management at Kyoto was flawed; there was no hierarchy of recursive levels to control the discourse and no regulator(s) so it was confusing to all.

\section{Interdependent solutions}

In the following section we note several procedural problems that seem to be repeated through succeeding UN 'climate change' meetings, and we offer three suggestions to alleviate the issues.

The Kyoto conference was messy - yet at the Durban (December, 2011) FCCC annual meeting there was again chaos as the local administrators (from South Africa, the host nation) attempted to reach a compromise between all decision makers over a common theme. This was an activity similar to earlier meetings -

a) Bali (2007) agreed the Bali Road Map. This, it was said, launched a new, comprehensive process to allow the full, effective and on-going implementation of the Convention through long-term collective action, now, up to, and beyond 2012, with the aim of reaching an agreed outcome and for adopting a resolution at Copenhagen (UNFCCC, 2012) 
b) Poznan (2008) a significant outcome was that governments agreed that the first draft of a positive negotiating text for a global climate change agreement should be available at a UNFCCC meeting in Bonn in June of 2009, with the target of adoption at Copenhagen

c) Copenhagen (2009) produced the Copenhagen Accord, which expressed legislative intent to limit carbon emissions and respond to climate change, in both the short and long term.

d) Cancun (2010) produced the basis for the most comprehensive and widespread international response to climate change the world had ever seen - to reduce carbon emissions and create a system which made all countries accountable to each other for those reductions.

e) Durban (2011) where a 'comprehensive' agreement by all delegates was agreed - essentially to try to extend the Kyoto Protocol from 2020 onwards.

These meetings were scheduled over 12 days or so to develop a draft agreement in time for government heads to attend and to sign-off the points over the last two days of meetings. This never occurred fully in any of the meetings, although fudges were concocted and signed-off in a blaze of publicity. At Durban the disorder was terrible. It resulted in an unscheduled two-day 24 by 24 hour extension, following some earlier days having all-night discussion sessions: no human decision maker can work in such conditions. This messy process was similar to an earlier EU meeting (EU debate, 2011) wherein an Ambassador, nameless of course, opined the accord was “... like the Loch Ness monster. We are familiar with it, but none has yet seen it”.

Working in parallel to the FCCC is the UN Intergovernmental Panel on Climate Change (IPCC) that gathers all scientific evidence on climate change. It is charged with issuing periodic summary reports: the Fifth is due in 2014, and it releases many intermediate reports. These reports are automatically written with the precise uncertainty that scientists and statisticians use. Sadly, neither managers nor laypersons intuitively understand the meaning of technical reports as we do not understand the language of rigorous statistical statements: that is “... the change will be $\mathrm{X}$ degrees, plus or minus $\mathrm{Z}$ degrees with a probability of $95 \%$ confidence”. Managers want to know if the result will be exactly $X$, and people in general want to know “... what it all means to us” in clear language.

The UN supports a Secretariat to develop matters towards and through these meetings. It is concerned primarily with the procedures and the organisation of meetings: most certainly the UN is not involved in the politics of the situation. As a result, in particular with regard to the science of climate change that has progressed on several fronts, we see political thrusts that need addressing but which the FCCC has no remit to address since currently the Convention recognises only three groups. There are the Annex I nations (basically the industrialised nations), Annex II nations (mainly developing nations), and the 49 LDCs (least developed countries), who have limited capacity to respond to climate change or to its adverse effects (UNFCCC, 2012/Parties). All negotiators by statute are to focus on emissions reductions and little else. For instance -

a) Science indicates that global ice packs are melting (at the North and South Pole, and the glaciers). The northern Arctic melt will have little effect (as with ice cubes floating then melting in a glass of water, no overflow takes place); but the increased sunlight on newly exposed water will cause it to expand as water is most dense at $4^{\circ} \mathrm{C}$. So many low lying islands across the globe will be flooded, and the people thereon will totally lose their national state. There is no forum in the FCCC to discuss 'displaced persons' which is an imminent situation deriving from global warming. Further, into the future, the science of the Antarctic indicates it is also melting, but as this is on-land glacial cover its fresh water will increase the sea levels. By how much is scientific speculation: if all the global ice melts the sea may rise by $\sim 80$ meters. If we restrict our view to 2100 the expected rise is between one and two 
metres. Clearly that has implications for the displacement of populations, and also with respect to international trade as most is carried by shipping that use ports. Ports are

constructed at sea level with some planned leeway between storm+high tide levels and the top of their quays - but what if these are more often breached; or worse, ports are totally flooded? International trade will reduce; global GDP will contract, etc...

b) The world population is increasing. Its rate of growth is quite sensitive to national variations in fertility rates: a medium rate forecast suggests a global growth until 2075 when it is predicted to recede from its peak - some 3 billion more than today (UNDESA, 2011). Clearly the forecasts have implications for global trade requirements and particularly on the eventual total emitted pollution through the industrial and transportation flux. In addition, we ought also to bear in mind the Millennium Development Goals (MDG) that increase pressure on many modes of pollution while we seek to better the lives of billions of vulnerable people (MDG, 2000).

c) Much of our pollution is caused by our needs - for electricity (mainly from coal), for chemical production (from gas and oil), and for transport (oil). As noted above, the 'peaks' of fossil fuel production vary - the oil peak has passed, gas will be 2025 or so, and coal somewhat later (Mohr, 2010). Thus, as the availability of all these fossil fuels diminish then our pollution output will fall - but there is inertia in the pollution production. Even if all pollution production ceased today, as there is a high gassing-off residual. This is yet another aspect argued at the FCCC.

At present the main group of the FCCC meetings is the Conference of the Parties (COP) which is supported by the Secretariat, but they are not competent in the annual meetings to cope with the broad discussions since both are regulated (by the UN) to work without reference to politics. A formal view of the interdependent committees is shown in UNFCCC (2012 /Bodies), but a contrasting view is offered by (Reeder, 2009). Reeder notes that at the Bonn meeting (June 2009) preceding the critical Copenhagen meeting the delegates agreed there would be two co-chairs for the future Durban meeting - one chair to be from a developed nation and the other from the developing world. There was no general agreement so the meeting decided that the chair would continue to be from the host nation, in Durban's case, South Africa.

We do not propose to disband the Secretariat since it works consistently to manage the complexity of the 'housekeeping'. It is a monumental task to organise the 'housekeeping' for maybe 20,000 accredited delegates: the host country needs support for this, as the host is responsible for all the logistics. Therefore, we recommend it remains active to advise the host nations about the organisation of future meetings. We note the Secretariat constitutionally does not do politics.

The Science Team (IPCC) works well (it produces and disseminates many reports): it must stay focused tightly on the science of climate change and its consequences: it talks science, not politics.

\section{Suggestion one}

We propose a new Operational Management team (OM) should be constituted to engage with all concerned in the future meetings - taking on board the findings of the IPCC, the agreements carried by COP, the arguments of Annex I and II and LDCs countries together with their politics, as well as the arguments of NGOs and lobbyists.

The new Operations Management team would work daily towards the production of the annual meeting agenda which would include all the climate change issues: pollutants and emissions, the 
many consequences of temperature changes on demographics, land productivity, sea levels, and so on; as well as the nuances of political inclinations and the cliques which may be formed between the 195 Parties of the Convention. By issuing consultation documents throughout the year they could diffuse the bitter arguments that kept delegates at the Durban tables for long hours during the formal meetings, and which extended into the comedy-noir of the 24 by 24 hour discussions of the two extra days at Durban.

Clearly the permanent teams - the new Operations Management team aided by the continuing Science team (IPCC) and the Secretariat - will have to generate sufficient variety to be a fully functioning 'regulator' in the Ashby sense. This is required as the current teams assess hundreds of conflicts, and now the Operations Management team must address the politics of all the nations be they developed, developing or LDCs (least developed countries), as well as the many NGOs with their own specific plan for saving the planet.

\section{Suggestion two}

This paper argues that Ashby's Law can help develop a mechanism for the control of climate change. However, the 'regulator' must be agreed and understood.

1) We suggest we must

a) Disaggregate the $\mathrm{CO}_{2}$ eq equation and delineate clearly the pollution drivers for each greenhouse gas looking carefully at national profiles - not just the production profiles, but also the economics of mitigation. This to be able to choose the best 'bang for the buck' in selecting a hierarchy of policies - which may vary according to the ability to respond by individual nations.

b) Come to an agreement about the science of climate change, and immediately pour money into new methods of potentially significant pollutant capture and $\mathrm{CO}_{2}$ sequestration. Of course, assessments of the corresponding effective efficiency must be taken into account.

c) Inform the public clearly that their efforts taken now will save the earth in the future, and they must be altruistic and share the global burdens.

Disaggregation of the $\mathrm{CO}_{2}$ eq composite measure ought to lead to a simpler and clarified scenario although we are hereby increasing variety. It will not be like the Montréal situation where key businesses had already agreed to change, and where the CFCs affected only a fraction of any nations' economy.

\section{Suggestion three}

We propose using a more complex regulator - the Viable Systems Model (Beer, 1972; 1979; 1981). VSM modelling includes Ashby's Law and integrates multiple levels of recursion to describe a complex process. Even so, these VSMs (for climate change) would still need to be restricted to particular economic sectors across instances - the world systems are too complex to fit into one large VSM application (Altshuller, 1984).

Yet work is being done on the application of VSM to large systems. Espinosa et al (2007) describes how non-hierarchical organisations, networks and complementarities may be modelled with complexity sciences. Others say it is possible to determine the invariant features of complex systems using "the systems approach" based on systems theory and cybernetics to propose broader mechanisms to move past the monolithic structural models within particular disciplines (Schwaninger, 2000). Agreeing with Altshuller, addressing the principles of complex systems, Bula and Espejo 
(2012) suggest that the lack of inclusion within a recursive system inhibits successful modelling of the larger complexity.

By adding an Operations Management group to the work of the UNFCCC we will be accepting the Level Ones of all the member states and creating Systems Two, Three and Four to better manage those System Ones and permitting policy guidance from the UN as a System Five. As the above papers suggest, large scale operations require much research and as yet there are no real exemplars.

\section{A 'splash of cold water'}

At the January 2012 World Economic Forum in Davos further research into trust was unveiled. The '2012 Trust Barometer' showed that we trusted less and less in our government officials or regulators (falling from $43 \%$ as polled in 2011 to $29 \%$ by 2012); we have grown away from trusting our CEOs (falling from 50\% to 38\%) - meanwhile the academic or expert remains the most trusted (at $68 \%$ ). Curiously, a category described as 'a person most like you' rose in trust level from $43 \%$ to $65 \%$ reflecting that we seem to trust more and more the messages in our media (trust in social media rose by $75 \%$ this year). The study found we must be told something three to five times before we believe it! (Edelman, 2012). This does not bode well for the meetings of the UNFCCC as we would doubt any outcome.

Further it would seem that individuals do not want to 'save the planet' as they once did over the 'ozone hole' since they see or hear the acrimonious discussions between nations - note reportage from the Durban meeting (Shah, 2012) - and thus become confused and lethargic. With respect to the largest global polluters, (a) the public know that politicians of both the Senate and Congress in the US are opposed to any agreement on pollution curbing which may hamper the economy of the US, while (b) the public know little of China's efforts at pollution curbing. Their $12^{\text {th }} 5$-year plan is tough on pollution control measures: this position was 'understood' within China (Horasis, 2010:33) prior to the $12^{\text {th }}$ PRC meeting and publically emphasized later (Xinhua, 2011; KPMG, 2011).

Individual apathy manifests itself differently round the world as individuals are not identical in China, Africa, and America and so on. Yet we all have similar drivers towards survival at a basic level - we need food, water and housing: but how we care for the planet is driven by what we learn in our formative years and by what we hear. As Kahan et al (2012) found “...When faced with having to support one side or the other in fundamental science debates, most people are influenced far more by their cultural and social worldviews than by solid science, no matter how well that science is presented. The public, especially those well-versed in science and mathematics, will usually agree with the perspective that comes closest to the values of the "tribe" with whom they most identify. In many cases, the facts do not matter at all". This is a rather worrying finding with respect to the future of climate change management with all its complexity and variety.

\section{Conclusions}

This paper has attempted to show that the Law of Requisite Variety has an application in climate change mitigation models and agreements. We have shown how the Law might have been retrospectively mapped to the Montréal (1987) protocol, and we noted that protocol of 1987 was very much simpler than the one being negotiated in Kyoto (1997). However, if the 'regulator' at Kyoto had been defined in less complex ways but with a greater variety, and if the flow of information had been sufficient to satisfy a set of new [mini] regulators addressing the complexity, there may have been a better chance of the Kyoto protocol being fully signed by all delegates. That this was not so 
has led to confusion at subsequent annual meetings: the worst performing was Durban in December 2011 at the time of the initial writing of this paper.

We propose that a more complex regulator be investigated using Beer's Viable Systems Model. This has the potential to absorb complexity and so might be able to cope better with the interdependent global climate changes affected by pollution, mitigation policies and above all, its politics.

\section{References}

AOSIS (2012) AOSIS Presses Loss and Damage in Bangkok (WWW document) http://aosis.org/ (Accessed $4^{\text {th }}$ September 2012).

Altshuller G S (1984) Creativity as an exact science: The theory of the solution of inventive problems. (Williams A: trans) Gordon \& Beech, London

Ashby W R (1956) An Introduction to Cybernetics. Chapman \& Hall, London

Ashby W R (1958) Requisite Variety and its Implications for the Control of Complex Systems. Cybernetica, 1(2), 83-99

Beer S (1972) Brain of the firm: the managerial cybernetics of organization. Penguin Books, London

Beer S (1979) Heart of Enterprise. Wiley, Chichester

Beer S (1981) Brain of the Firm: Second Edition. London, Wiley, London

Benedick R E (2004) The improbable Montréal protocol: Science, diplomacy, and defending the ozone layer. http://www.ametsoc.org/atmospolicy/documents/Benedickcasestudy_000.pdf (Accessed on February $12^{\text {th }} 2010$ )

Bula G, Espejo R (2012) Governance and inclusive democracy, Kybernetes, 41 (3/4), 339 - 347

Edelman R (2012) About trust - the 2012 barometer. http://trust.edelman.com/ (Accessed 17 ${ }^{\text {th }}$

September 2012)

EIA (2009) International Energy Outlook 2009. Energy Information Administration (EIA). http://www.eia.doe.gov/oiaf/ieo/index.html. (Accessed September $12^{\text {th }} 2009$ ).

EU Debate (2011) Debates of the European Parliament. Wednesday $16^{\text {th }}$ November: Wolf Klinz, page 31. (WWW document) http://www.europarl.europa.eu/RegData/seance_pleniere/compte_rendu/traduit/2011/1116/P7 CRE(2011)11-16 EN.pdf (Accessed 10 ${ }^{\text {th }}$ October 2012).

Espejo R \& Harnden R (eds) (1989) The Viable System Model. John Wiley, London

Espinosa A, Harnden R \& Walker J (2007) Beyond hierarchy: a complexity management perspective, Kybernetes, 36 (3/4), 333 - 347

Farman J C, Gardiner B G \& Shanklin J D (1985) Large losses of total ozone in Antarctica reveal seasonal COx/NOx interaction. Nature 315, 207-10.

Giddens A (2008) The politics of climate change: National responses to the challenge of global warming. London, The Policy Network. 
Hammer C U, Clausen H B \&Tauber H (1986) Ice-Core Dating of the Pleistocene/Holocene Boundary Applied to a Calibration of the 14c Time Scale. Radiocarbon 28, 284-91.

Hansen J, Sato M, Kharecha P, Russel G, Lea D W \& Siddall M (2007) Climate Change and Trace Gases. Philosophical Transactions of the Royal Society A. 365, 1925-1954

Horasis (2010) Global China Business Meeting. Luxemburg, November 21 - 22, 2010. http://www.horasis.org/event china 2010 after.php. (Accessed $20^{\text {th }}$ September 2012).

Hilder T (1995) Stafford Beer's Viable System Model: An interpretation. Cavendish Software Ltd., Trowbridge.

IPCC (2007) Climate Change 2007: 4th assessment report. See http://www.ipcc.ch (Accessed 12 $2^{\text {th }}$ September 2010)

Kahan D M, Peters E, Wittlin M, Slovic P, Ouellette L L, Braman D, and Mandel G (2012) The polarizing impact of science literacy and numeracy on perceived climate change risks. Nature Climate Change. Online publication 27 May 2012, http://www.nature.com/nclimate/journal/vaop/ncurrent/full/nclimate1547.html Accessed 4th September 2012.

Keeling C D, Bacastow R B, Bainbridge A E, Ekdahl Jr C A, Guenthe P R, Waterman L S \& Chin J F S. (1976) Atmospheric Carbon Dioxide Variations at Mauna Loa Observatory. Tellus 28, 53851.

KPMG (2011) (WWW document) China-12th-Five-Year-Plan-Overview-2011. www.kpmg.com (Accessed 20th September 2012).

MDG (2000) We the Peoples: The role of the United Nations in the $21^{\text {st }}$ century. UN Department of Public Information, New York

Mohr S (2010) Projection of world fossil fuel production with supply and demand interactions. PhD Thesis. University of Newcastle, Australia. http://ogma.newcastle.edu.au:8080/vital/access/manager/Repository/uon:6530. (Accessed February $20^{\text {th }}$ 2012).

Molina M J \& Rowland F S (1974) Stratospheric Sink for Chlorofluoromethanes: Chlorine AtomCatalysed Destruction of Ozone. Nature 249, 810-2

Morrisette P M (1989) The evolution of policy responses to stratospheric ozone depletion. Natural Resources Journal 29, 793-820. See also http://www.ciesin.org/docs/003-006/003-006.html. (Accessed 20 ${ }^{\text {th }}$ September 2012).

POST (2006) Carbon Footprint of electricity generation. London, Parliamentary Office of Science and Technology (POST), October \# 268

Reeder G (2009) Disagreements and distrust over chairmanship of the Durban Platform. http://www.earthinbrackets.org/2012/05/19/disagreements-and-distrust-over-chairmanship-ofthe-durban-platform/ (Accessed 22 ${ }^{\text {nd }}$ September 2012). 
Revelle R, Folsom T R, Goldberg E D \& Isaacs J D (1955) Nuclear science and oceanography. Presentation at the United Nations International Conference on the Peaceful Uses of Atomic Energy, Geneva, Paper A/CONF.8/P/277

Roberts J T \& Parks B C (2006) A Climate of Injustice Global Inequality, North-South Politics, and Climate Policy. MIT Press, Boston, MA.

Shah A (2012) COP17 - Durban Climate Conference. http://www.globalissues.org/article/797/cop17-durban-climate-conference. (Accessed 20th September 2012).

Schwaninger M (2000) Managing Complexity—The Path Toward Intelligent Organizations. Systemic Practice and Action Research, 13 (2), 207 - 241

Schneider M \& Froggatt A (2008) The World Nuclear Industry: Status Report. Greens-EFA Group in the European Parliament, Brussels.

Stuiver M \& Suess H E (1966) On the Relationship between Radiocarbon Dates and True Sample Ages. Radiocarbon 8, 534-40.

UNFCCC (1999) Offsetting the carbon footprint for Copenhagen.

http://unfccc.int/press/news room/newsletter/items/5096.php (Accessed at 4th September 2012).

UNFCCC Key data (2012) http://unfccc.int/6240.php (Accessed at 4th Sept 2012).

UNFCCC Bodies (2012) http://unfccc.int/bodies/items/6241.php. (Accessed at $4^{\text {th }}$ September 2012).

UNFCCC Fact Sheet (1999) Minimising the Copenhagen carbon footprint. http://unfccc.int/press/fact_sheets/items/5055txt.php (Assessed $4^{\text {th }}$ September 2012).

UNFCCC Parties (2012) http://unfccc.int/bodies/items/6241.php. (Accessed at $4^{\text {th }}$ September 2012).

UNDESA (2011) World Population Prospects, the 2010 Revision. http://esa.un.org/unpd/wpp/index.htm (Accessed $16^{\text {th }}$ September 2012).

UNDP (2000) Millennium Development Goals. http://www.undp.org/content/undp/en/home/mdgoverview.html $\quad$ (Accessed $4^{\text {th }}$ September 2012).

UNEP (2010) Scientific depletion of ozone depletion. World Meteorological Organisation, Global Ozone Research \& Monitoring project - Report 52. UN Environment Program, Geneva.

Weart S (2008) The Discovery of Global Warming: Revised and Expanded Edition. Harvard University Press, Boston, MA. Also see http://www.aip.org/history/climate/index.html\#contents

Xinhua (2011) Key targets of China's 12th five-year plan. http://news.xinhuanet.com/english2010/china/2011-03/05/c_13762230.htm (Accessed 20th September 2012). 